\title{
Micropsectra arduinna sp.n. (Diptera: Chironomidae, Tanytarsini), a new brachypterous species inhabiting acid peat bogs located in NE-France
}

\section{Micropsectra arduinna sp.n. (Diptera: Chironomidae, Tanytarsini), новый брахиптерный вид из кислотных торфяных болот северо-востока Франщии}

\author{
J. Moubayed-Breil*, G. Coppa** \\ Аж. МобайеА-БрейА*, Г. Коппа**
}

* 10 Rue des Fenouils, Montpellier F-34070 France. E-mail: mvp5133@gmail.com.
* 10 -я ул. Фенуи, Монтпелье, Франция.
** 1 rue du Courlis, Villers-sur-Bar F-08350 France. E-mail: gennaro.coppa@wanadoo.fr.
** ул. Керлью, Вилле-сюр-Бар, Франция.

Key words: Chironomidae, Micropsectra arduinna, brachypterous, acid peat bogs, NE-France, new species.

Ключевые слова: Chironomidae, Micropsectra arduinna, брахиптерный вид, кислотные торфяные болота, северо-восток Франции, новый вид.

Abstract. The male adult of Micropsectra arduinna Moubayed-Breil, sp.n. is described, the diagnosis based on material recently collected in low land acid peat bogs (alt. 250-300 m) located in the department of Ardennes (NEFrance). Taxonomic notes provided include some comparative characters found in the male adult of $M$. uliginosa (Reiss, 1969), which is considered to be a sister species of $M$. arduinna Moubayed-Breil, sp.n. The distribution of M. arduinna Moubayed-Breil sp.n. is currently restricted to its type locality. Remarks on taxonomic position, and ecology of the new described species are given.

Резюме. Приведено иллюстрированное описание имаго самца Micropsectra arduinna Moubayed-Breil sp.n. по материалу, собранному у торфяного болота с кислой $\mathrm{pH}$ среды на высоте 250-300 м н.у.м. в провинции Арденн (северо-восток Франции). Брахиптерные самцы M. arduinna Moubayed-Breil, sp.n. и M. uliginosa (Reiss, 1969) имеют много общих морфологических признаков, и поэтому их можно считать близкородственными видами. Географическое распространение M. arduinna MoubayedBreil sp.n. ограничено типовым местообитанием. Также даны замечания, таксономическое положение и экология нового вида.

\section{Introduction}

In this paper a new brachypterous Micropsectra arduinna sp.n. is described and diagnosed as male adult based on material recently collected in low land acid peat bogs (altitude 250-300 m) located in the department of Ardennes (NE-France). On the basis of some relevant characters found in the male adult of both M. arduinna sp. n. and M. uliginosa (Reiss, 1969) these two brachypterous species appear to be closely related and therefore are both considered as sister species. According to Shilova [1976], Reiss [1969, 1971,
1982, 1983], Langton and Ruse [2006], Murray and Baars [2006], Giłka [2009, 2011], Ekrem et al. [2010], Giłka and Jazdzewska [2010] currently there is six known species of the genus Parapsectra Reiss, 1969 which are actually included in the genus Micropscetra Kieffer, 1909: $M$. bumasta (Giłka et Jazdzewska, 2010), M. chionophila (Edwards, 1933), M. nana (Meigen, 1818), M. styriaca (Reiss, 1969), M. uliginosa (Reiss, 1969), M. wagneri (Siebert, 1979). Consequently the description of M. arduinna sp.n. increases to seven the total number of the latter group of Micropsectra species. The recent updated list of 767 species previously provided for continental France in Moubayed-Breil et Ashe [2016, 2018a, b], Moubayed-Breil [2017] and Moubayed-Breil and Dia [2017] was upgraded to 768 valid known Chironomid species in Moubayed-Breil [2018]. Consequently, the description of $M$. arduinna sp. n. currently increases the total number to 769 known Chironomid species from this country. Morphological terminology and measurements follow that of Saether [1980] for the imagines. Remarks and discussion on the nearest related Micropsectra species and comments on the ecology and geographical distribution of the new species are given. Holotype (on 1 slide) is deposited in the collections of the Zoologische Staatssammlung (ZSM), Munich, Germany. Type material was preserved in 80-90\% alcohol, and later mounted in polyvinyl lactophenol. For each adult, the head, thorax and abdomen were cleared in $90 \%$ lactic acid then washed in 60-70\% ethanol before mounting on slides.

\section{Micropsectra arduinna Moubayed-Breil, sp.n.}

Figs $1-3,6 ; 8-11 ; 15-21$.

Type material. Holotype: 1 male adult, France, Acid peat bogs, Signy-Le-Petit wetland area (Department of Ardennes, NE-France), upper basin of the River La Gland, altitude 250- 

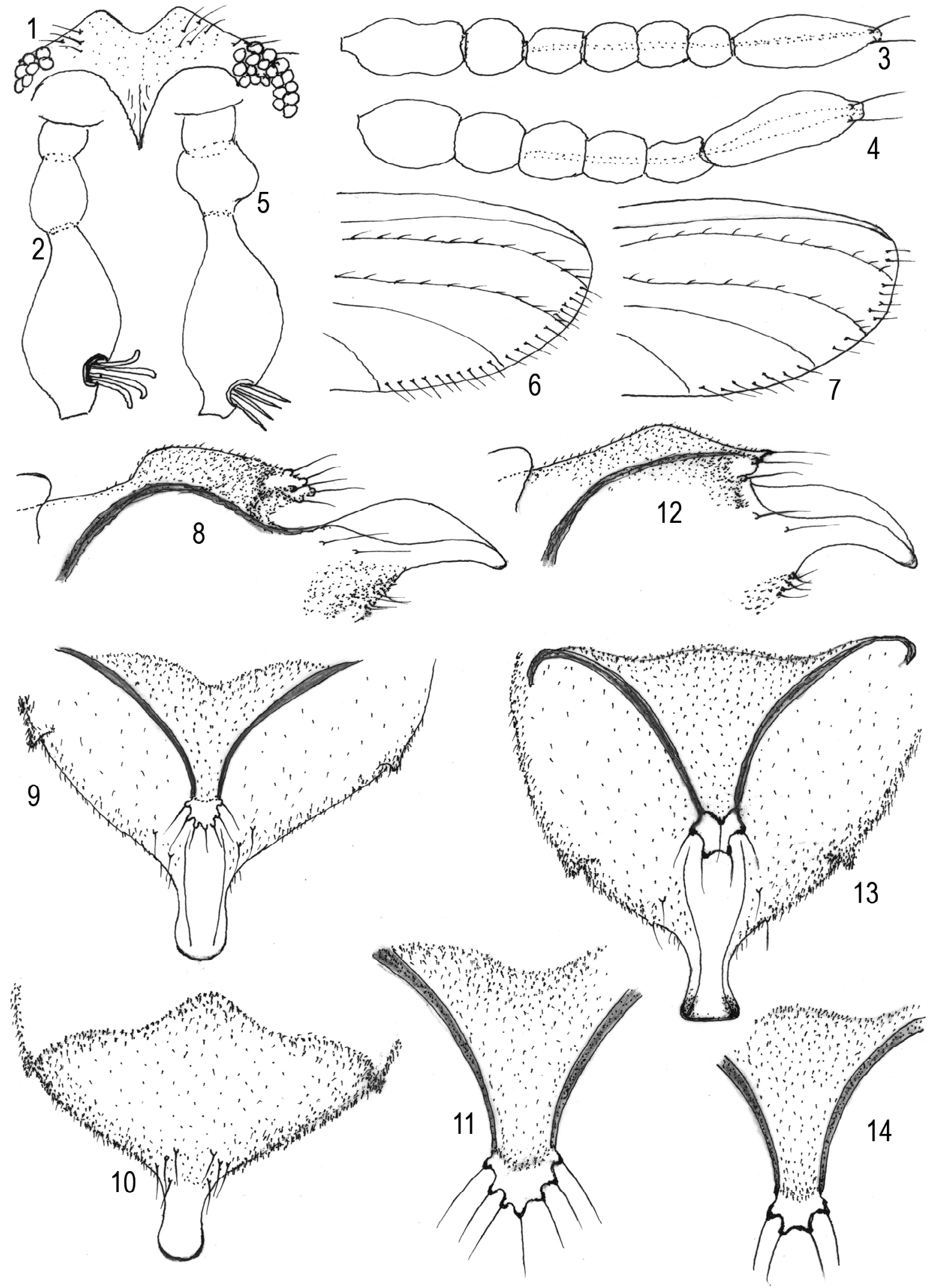
Table 1. Micropsectra arduinna sp.n.: length $(\mu \mathrm{m})$ and proportions of legs

Таблица 1. Micropsectra arduinna sp.n.: Алина $(\mu \mathrm{m})$ и пропорџии ног

\begin{tabular}{|c|c|c|c|c|c|c|c|c|c|c|c|}
\hline $\mathrm{P}$ & $\mathrm{fe}$ & $\mathrm{ti}$ & $\mathrm{ta}_{1}$ & $\mathrm{ta}_{2}$ & $\mathrm{ta}_{3}$ & $\mathrm{ta}_{4}$ & $\mathrm{ta}_{5}$ & $\mathrm{LR}$ & $\mathrm{BV}$ & $\mathrm{SV}$ & $\mathrm{BR}$ \\
\hline $\mathrm{PI}$ & 595 & 460 & 510 & 215 & 175 & 130 & 90 & 0.90 & 2.40 & 2.60 & 1.31 \\
\hline PII & 490 & 440 & 150 & 85 & 65 & 55 & 60 & 0.34 & 4.00 & 6.20 & 0.71 \\
\hline PIII & 605 & 555 & 230 & 145 & 130 & 80 & 65 & 0.41 & 3.31 & 5.04 & 1.70 \\
\hline
\end{tabular}

300 m; leg. Gennaro Coppa, 17.IV.2016 (Fig. 26). Environmental data of water are: moderately crystalline water, conductivity about $20-30 \mu \mathrm{S} / \mathrm{cm}$; temperature $6-15{ }^{\circ} \mathrm{C}$.

Etymology. The species name 'arduinna' belongs to the known religious Goddess 'Arduinna', which is one of the many Celtic Goddesses who is associated with a particular territory or body of water. Arduinna is derived from the Gaulish 'arduo' (meaning height) and refers to the eponymous tutelary goddess of the Ardennes Forest and Regions delimited by the current day Belgium and Luxembourg with small portions found in France and Germany.

Diagnosis. M. arduinna sp.n. represents a sister species of $M$. uliginosa based on close resemblance of some features found in the male adult. However, the new described species can be separated from other European members of the genus in having: palpomere 3 much longer than fourth; sensilla coeloconica on palpomere 3 tubule-like; number and location of setae on cells of wing differently figured; elevated hump and dorsal tubercles on tergite IX markedly projecting; anal point drop-like with rounded apex; median volsella with short stem, bent downwards, bearing often fusiforme setae; inferior volsella markedly wider at base than in median part, setiferous ventral lobe consists of 5 setae (placed: 1 medially, 2 on outer margin, 2 posteriorly; gonostylus slender, swollen medially, distal half distinctly tapering to a pointed apex.

Description. Male imago $(\mathrm{n}=1$, brachypterous male adult; Figs $1-3,6,8-11,15-21)$. A very small sized $\mathrm{Mi}$ cropsectra species. Total length $1.75 \mathrm{~mm}$. Wing length 0.70 $\mathrm{mm}$. TL/WL 2.5. Colouration pale to brown with contrasting brown to dark brown head, thorax, abdominal segments and anal segment. Tergites I-VI with two lateral brownish bands, which are markedly converging towards the posteromedian area.

Head (frontal and temporal parts, Fig. 1). Eyes bare; hairs present on distal half of inner margin of eyes; frontal margin markedly gaping medially, with two distinct semi-circular projections placed on each side of the coronal suture; coronal triangle well represented; frontal tubercles absent. Temporal setae 8 including 5 inner and 3 outer verticals. Clypeus rectangular with 16 setae in 5 rows. Palp (Fig. 2) 5-segmented; length (in $\mu \mathrm{m}$ ) of segments 1-5: 20, 28, 83, 67, 89; palpomere 4 strongly shorter than third; palpomere 3 with tubule-like sensilla coeloconica. Antenna (Fig. 3) 7-segmented, $261 \mu \mathrm{m}$ long; length ( $\mu \mathrm{m})$ of segments: 55, 35, 32, 32, 32,
20,75; ultimate flagellomere clubbed and bearing 2 pre-apical setae; antennal groove reaching segments 3; AR 0.40.

Thorax. Lobes of antepronotum widely gaping; antepronotals, acrostichals and prealars absent; dorsocentrals 11 including 8 grouped proximally and 3 placed distally; humeral pit oval and small sized. Scutellum (Fig. 20) with 6 setae placed laterally in 1 row ( 3 on each side), the mostly located lateral seta is much smaller; median area bare.

Wing. General form as in M. uliginosa, markedly reduced, linear and spatulate; maximum width $110 \mu \mathrm{m}$; brachiolum with 2 setae; distribution pattern of setae on veins and cells as shown in Fig. 6); number of setae on veins: $\mathrm{R} 11-12$; $\mathrm{R}_{1}$ $11-13 ; \mathrm{R}_{2+3} 0 ; \mathrm{R}_{4+5} 9-10$; remaining veins bare; number of setae on cells: $\mathrm{r}_{2+3}, 0 ; \mathrm{r}_{4+5}, 5-6 ; \mathrm{m}_{1+2}, 5 ; \mathrm{m}_{3+4}, 9-10 ;$ an, $1-2$. Squama bare.

Legs. Length (in $\mu \mathrm{m}$ ) of tibial spurs: PI, 10; PII, 65 and 10; PIII, 75 and 50. Tibial combs of PII and PIII vestigial with about 10 short teeth $(5-10 \mu \mathrm{m}$ long), separated by about 60 $\mu \mathrm{m}$. Tarsomeres ta $-\mathrm{ta}_{4}$ of PII much shorter than those of PI and PIII; the ratio (length of tarsomeres $\mathrm{ta}_{1}-\mathrm{ta}_{5}$ of PI divided by that of $\mathrm{ta}_{1}-\mathrm{ta}_{5}$ of PII) is as follows: $3.4,2.5,2.5,2.4,1.5$; maximum value of BR (1.31-1.70) is recorded on PI and PIII, lowest value (0.71) belongs to PII; highest values of SV are those of PII (6.20) and PIII (5.04); sensilla chaetica present on tarsomeres ta to ta $_{5}$ of PI, PII and PIII. Length $(\mu \mathrm{m})$ and proportions of legs as in Table 1.

Hypopygium (Figs 15-19) as illustrated in dorsal (Fig. 15) and ventral view (Fig. 16, with anal point and tergite IX removed). Tergite IX $180 \mu \mathrm{m}$ maximum width at base, subrectangular and narrowing distally; presence of a dorsal projecting elevated hump on median area (clearly visible in lateral view, Fig. 8), is bearing seven small tubercles with 1 seta each (clearly visible in dorsal view, Figs 9, 11, 15); setae on apical part of the dorsal hump as shown in Figs 9, 11 and 15; teeth on median part of lateral margin present; anal tergite bands (Figs 9, $11,15)$ converging towards base of the median tubercles; posteromedian area delimited by the anal tergites bands gaping medially at base and covered with dense microtrichia. Anal point (Fig. 8, lateral; Figs 9, 15, dorsal; Fig. 10, ventral) about $60 \mu \mathrm{m}$ long and $20 \mu \mathrm{m}$ maximum width at distal part; distinctly drop-like shaped, constricted medially and ending with rounded apex; a long crest (Figs 8, 9, 15) is extending from base to distal part; base with $4-5$ dorsal setae and about 8 setae inserted ventrally. Sternapodeme orally directed medially, bear-

Figs 1-14. Imago males of Micropsectra arduinna (1-3, 6, 8-11), and M. uliginosa (2-5, 7, 12-14): 1 - head, frontal and temporal areas, 2 - palpomeres $1-3,3$ - antenna, 4 - antenna, 5 - palpomeres $1-3.6-7$ - distal half of wing of M. arduinna sp.n. (6), and M. uliginosa (7). 8-10 - tergite IX and anal point in lateral (8), dorsal (9) and ventral view (10); 11 - dorsal tubercle of tergite IX; 12 - tergite IX and anal point, lateral view; 13 - tergite IX and anal point, dorsal view; 14 - dorsal tubercle of tergite IX.

Рис. 1-14. Имаго самщы Micropsectra arduinna $(1-3,6,8-11)$ и M. uliginosa $(2-5,7,12-14)$ : 1 - голова, фронтальная и темпорамьная области; 2 - 1-3 чменики максимяярного щупика; 3, 4 - антенна; 5 - 1-3 чменики максимярного щупика. 6-7 - дистальная половина крыла M. arduinna sp.n. (6) и M. uliginosa (7). M. arduinna sp.n. (8-10): тергит IX и анамьный отросток, виА сбоку (8), то же, виА сверху (9) и снизу (10); 11 - дорсальный бугорок на тергите IX; 12 - тергит IX и анальный отросток, виА сбоку; 13 - тергит IX и анальный отросток, виА сверху; 14 - дорсальный бугорок на тергите IX. 


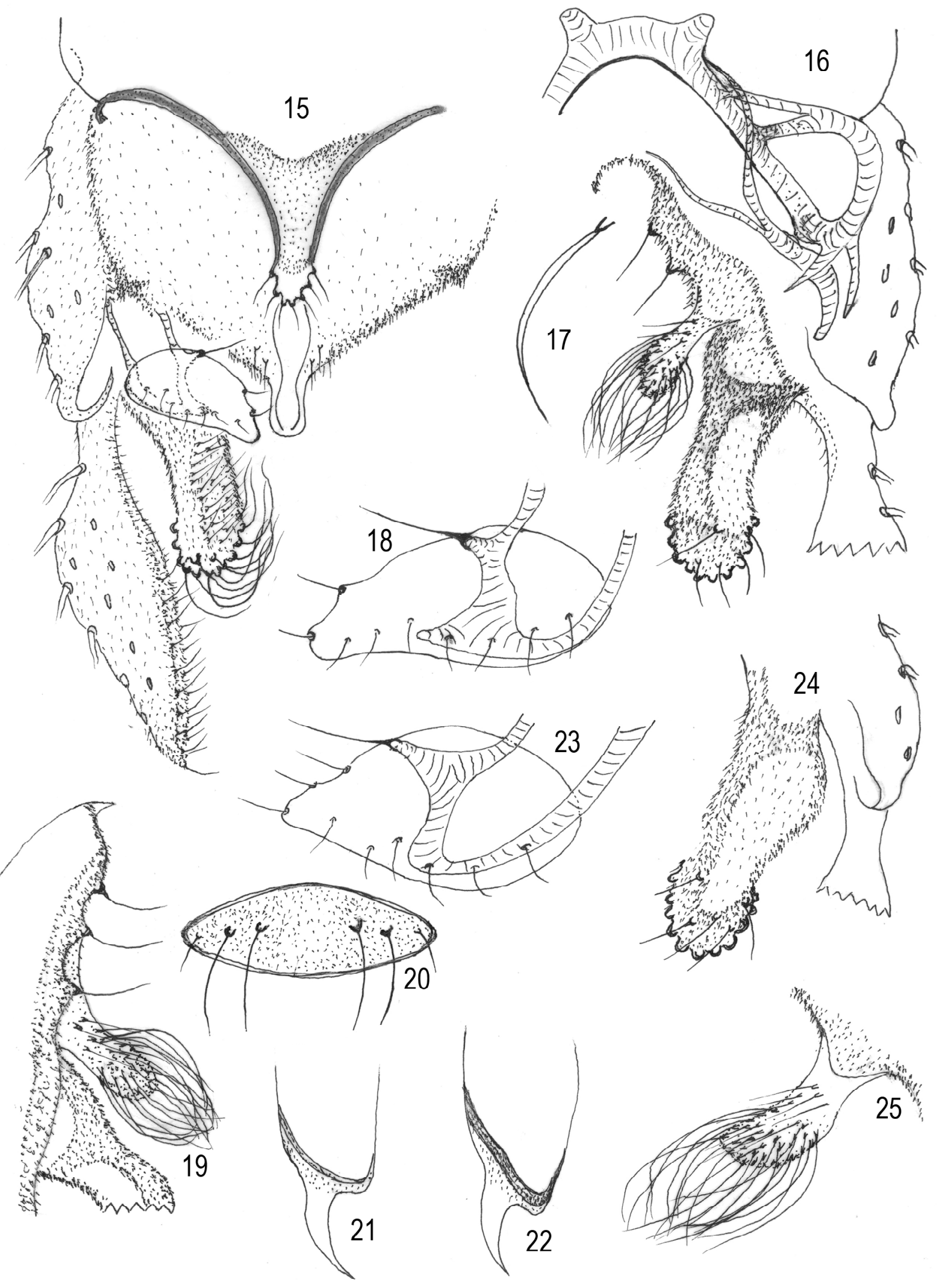




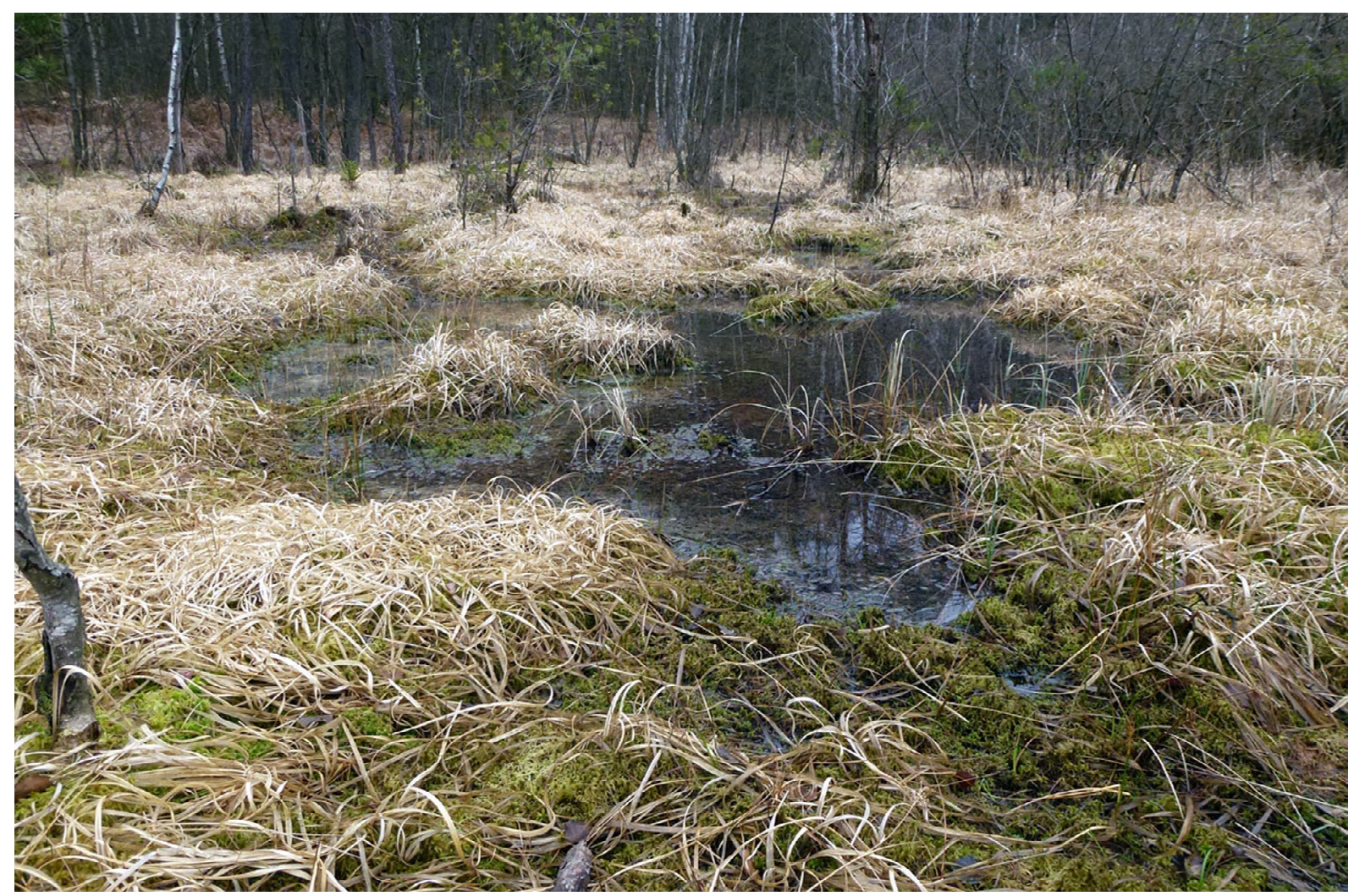

Fig. 26. Acid peat bogs at Signy-le-Petit (type locality, NE-France), upper basin of the River La Gland, altitude 250-300 m (Photo of Gennaro Coppa, 17.IV.2016).

Fig. 26. Кислотные торфяные болота у Сигни-Ае-Петит (типовое местообитание, северо-восток Франции), верхний бассейн р. Аа Гканд, высота над уровнем моря 250-300м (Фото Геннаро Коппа, 17.IV.2016).

ing two characteristic lateral horn-like projections; coxapodeme composed of a linear elongate inner part which turns over at base to join the upper outer part; phallapodeme crescentlike at base and bifurcate apically, outer branch projecting upwards to join the upper part of coxapodeme. Superior volsella (Figs 15, 18), $75 \mu \mathrm{m}$ long and $30 \mu \mathrm{m}$ maximum width; microtrichia absent; swollen proximally and narrowing distally; anterior margin convex in its proximal part, sinuous distally with setal protuberances; digitus stout and short, overreaching half length of superior volsella, Micropsectra-seta placed on a distinct short tubercle; surface with 2 setae on inner anterior margin and 7 smaller setae on posterodorsal area. Median volsella (Figs 16,19$)$ about $60 \mu \mathrm{m}$ long and $45 \mu \mathrm{m}$ maximum width, distinctly bent downwards, consists of a short stem spherical to bulbous distally, bearing about 17-20 setae which are parallel-sided basally and fusiforme distally (Fig. 17). Inferior volsella (Figs 15-16) about $120 \mu \mathrm{m}$ long and $40 \mu \mathrm{m}$ maximum width; base markedly wider than median part; dorsal side (Fig. 15) with 29-32 setae including 19-21 relatively short (located medially in 2-3 longitudinal rows) and 10-11 longest (inserted close to the posterior margin); setiferous ventral lobe
(Fig. 16) is composed of 5 setae (placed: 1 medially, 2 on outer margin, 2 posteriorly). Gonocoxite $150 \mu \mathrm{m}$ long, with 8 9 setae. Gonostylus (Fig. 15) $190 \mu \mathrm{m}$ long and about $40 \mu \mathrm{m}$ maximum width, slender, moderately swollen medially, tapering in its distal half to a pointed apex; median and distal inner margin bearing 1-2 row of 8-10 fine long setae. HR 0.79 .

Pupal and larva unknown.

Taxonomic remarks. M. arduinna sp.n. and M. uliginosa belong to two closely related species: both are brachypterous, small sized Micropsectra species and characterized by some similar morphological features found in the male adult. Therefore, these two species can be considered as sister species. However, M. arduinna sp.n. can be separated from M. uliginosa based on comparative taxonomic data from the literature [Reiss 1969, Figs 1-6; Giłka and Jazdzewska 2010, Figs 6, 25-28] or, on the following summarized distinguishing relevant characters provided in Table 2.

Ecology and geographical distribution. The male adult of $M$. arduinna sp.n. is collected in the acid peat bog of Sevigny-Le-Petit (type locality, North Eastern France, altitude 250-300 m). Emergence is recorded in April.

Figs 15-25. Imago males of Micropsectra arduinna (15-21), and M. uliginosa (22-25): 15-16 - hypopygium in dorsal (15) and ventral view; 16 - tergite IX and anal point removed; 17 - seta of median volsella; 18 - superior volsella; $19-$ median volsella and base of inferior volsella; 20 - scutellum; 21 - femoral claw of PII; 22 - femoral claw of PII; 23 - superior volsella; 24 - inferior volsella, ventral view; 25 - median volsella.

Рис. 15-25. Имаго самџы Micropsectra arduinna (15-21) и M. uliginosa (22-25): 15-16 - гипопигий, виА сверху (15) и вид снизу; 16 - тергит IX и анальный отросток удалены; 17 - щетинка медиального придатка; 18 - верхний придаток; 19 - медиальный придаток и основание нижнего придатка; 20 - скутеммюм; 21 - крючок бедра на средней ноге; $22-$ femoral claw of PII; 23 - верхний придаток; 24 - нижний придаток, вентральный виА; 25 - медиальный придаток. 
Table 2. Main differentiating characters in the male adults of Micropsectra arduinna sp.n. and M. uliginosa

Таблица 2. Сравнительная характеристика основных морфологических признаков самцов Micropsectra arduinna sp.n. и M. uliginosa

\begin{tabular}{|l|l|l|}
\hline Main distinguishing characters & \multicolumn{1}{|c|}{ M. arduinna sp.n. } & \multicolumn{1}{|c|}{ M. uliginosa (Reiss, 1969) } \\
\hline $\begin{array}{l}\text { Sensilla coeloconica on } \\
\text { palpomere 3 }\end{array}$ & Tubule-like with rounded apex & Tubule-like with pointed apex \\
\hline $\begin{array}{l}\text { Distribution of setae on cells: } \\
\text { Figs 6-7 }\end{array}$ & $\begin{array}{l}\mathrm{r}_{2+3}, 0 / \mathrm{r}_{4+5}, 5-6 / \mathrm{m}_{1+2}, 5 / \mathrm{m}_{3+4}, 10 / \\
\text { an, } 1-2\end{array}$ & $\begin{array}{l}\mathrm{r}_{2+3}, 2 / \mathrm{r}_{4+5}, 5 / \mathrm{m}_{1+2}, 2 / \mathrm{m}_{3+4}, 7-8 \\
/ \text { an, } 0\end{array}$ \\
\hline Tergite IX & Sub-rectangular & Semi-circular \\
\hline Hump of tergite IX & Well elevated and projecting & Low and not projecting \\
\hline Dorsal tubercles of tergite IX & Number, 7 & Number, 4-5 \\
\hline $\begin{array}{l}\text { Dorsal area between tergite } \\
\text { bands }\end{array}$ & Distinctly gaping medially ad base & Convex medially at base \\
\hline Anal point & Drop-like with rounded apex & Not drop-like, with truncate apex \\
\hline Median volsella & Bent downwards & Slightly projecting upwards \\
\hline Setae on median volsella & $\begin{array}{l}\text { Parallel-sided basally, fusiforme } \\
\text { apically }\end{array}$ & $\begin{array}{l}\text { Falciform (basally), fusiforme } \\
\text { apically) }\end{array}$ \\
\hline Inferior volsella & Base wider than median part & Median part wider than base \\
\hline Gonostylus & Slender and tapering; apex pointed & $\begin{array}{l}\text { Bulbous, not tapering; apex not } \\
\text { pointed }\end{array}$ \\
\hline
\end{tabular}

\section{Acknowledgments}

I wish to thank my colleague Dr. Oksana V. Orel (Federal Scientific Center of the East Asia Terrestrial Biodiversity, Far East Branch of the Russian Academy of Sciences).

\section{References}

Cranston P.S., Dillon M.E., Pinder L.C.V., Reiss F. 1989. The adult males of Chironominae (Diptera: Chironomidae) of the Holarctic Region-Keys and diagnoses. Wiederholm, T. (Ed.): Chironomidae of the Holarctic region. Keys and diagnoses Part 3. Adult males // Entomologica scandinavica. Suppl.4. P.353-502.

Ekrem T., Willassen E., Stur E. 2010. Phylogenetic utility of five genes for dipteran phylogeny: a test case in the Chironomidae leads to generic synonymies // Molecular Phylogenetics and Evolution. Vol.57. P.561-571.

Giłka W. 2009. Order Diptera, family Chironomidae Tribe Tanytarsini // Arthropod Fauna of the UAE. Vol.2. P.667682

Giłka W. 2011. Ochotkowate - Chironomidae, plemię: Tanytarsini, postaci dorosłe, samce. Klucze do oznaczania owadów Polski. [Non-biting midges - Chironomidae, tribe Tanytarsini, adult males. Keys for the Identification of Polish Insects]. Nr 177 serii kluczy. Cześśc XXVIII, MuchówkiDiptera, zeszyt 14b. Polskie Towarzystwo Entomologiczne. Biologica Silesiae, Wrocław, 95 str. P.1-95.

Giłka W., Jazdzeweska N. 2010. A systematic review of the genus Parapsectra Reiss (Diptera: Chironomidae: Tanytarsisni) with description of a new species from Poland // Zootaxa. Vol.2350. P.1-21.

Langton P.H., Ruse L.P. 2006. Further species of Chironomidae (Diptera) new to the British Isles and data for species newly recorded in 1988 Checklist // Dipterists Digest (Second Series). Vol.12. P.135-140.

Moubayed-Breil J. 2017. On the genus Chaetocladius (laminatusgroup). I. Taxonomic notes with description of C. guisseti sp.n. from glacial springs and streams located in Eastern
Pyrenees (Diptera: Chironomidae, Orthocladiinae) // Evraziatskii Entomologicheskii Zhurnal (Euroasian Entomological Journal). Vol.16. No.5. P.487-500.

Moubayed-Breil J., Ashe P. 2016. New records and additions to the database on the geographical distribution of some threatened chironomid species from continental France (Diptera, Chironomidae) // Ephemera. Vol.16. No.2. P.121-136.

Moubayed-Breil J., Ashe P. 2018a. Cricotopus (s. str.) latellai sp. n., a new rheophilic species of the tremulus-group, inhabiting glacial streams located in both the Italian and French Maritime Alps (Diptera: Chironomidae). In preparation.

Moubayed-Breil J., Ashe P. 2018b. Chironomidae (Diptera) from the coastal Mediterranean ecosystem of continental France. I. Faunal comparative data since the last four decades (Diptera, Chironomidae). In preparation.

Moubayed J., Dia A. 2017. Chaetocladius coppai sp.n. and C. diai sp.n., two mountain relic species inhabiting glacial springs and cold streams (Diptera: Chironomidae, Orthocladiinae) // Zoosystematica Rossica. Vol.26. No.2. P.369-380.

Murray D.A., Baars J.R. 2006. Parapsectra uliginosa Reiss, 1969 (Diptera, Chironomidae) new to Ireland and association of exuviae of Procladius Pe1 (sensu Langton) with P. simplicistilus Freeman, 1948 // Dipterists Digest. Vol.13. P.166-168.

Reiss F. 1969. The new chironomid genus Parapsectra (Diptera) of European distribution, with a brachypterous species from moors // Archiv für Hydrobiologie. Vol.66. No.2. P.192-211.

Reiss F. 1971. Parapsectra chionophila (Edw.), eine dritte Art der Gattung aus Europa (Diptera: Chironomidae) // Gewässer und Abwässer. Vol.51-52. P.79-82.

Reiss F. 1982. Beschreibung der Puppe von Parapsectra styriaca (Reiss) nov. comb. (Diptera: Chironomidae) // Nachrichtenblatt der Bayerischen Entomologen. Vol.31. P.121-124.

Reiss F. 1983. Parapsectra mendli n.sp. (Diptera, Chironomidae) aus dem Allgäu, Bayern // Spixiana. Vol.6. P.79-81.

Sæther O.A. 1980. Glossary of chironomid morphology terminology (Diptera, Chironomidae) // Entomologica scandinavica. Suppl.14. P.1-51.

Shilova A.I. 1976. Khironomidy Rybinskogo Vodokhranilishcha [Chironomids of the Rybinsk Water Reserve]. Leningrad: Nauka. P.1-251. [In Russian]. 